\title{
A Nurse Case Management HIV Prevention Intervention (Come As You Are) for Youth Experiencing Homelessness: Protocol for a Randomized Wait-list Controlled Trial
}

Diane Santa Maria ${ }^{1}$, BSN, MSN, DrPH; Marguerita Lightfoot ${ }^{2}$, PhD; Adey Nyamathi ${ }^{3}$, BSN, PhD; Michael Businelle ${ }^{4}$, PhD; Mary Paul ${ }^{5}$, MD; Yasmeen Quadri ${ }^{6}$, MD; Nikhil Padhye ${ }^{1}$, PhD; Jennifer Jones ${ }^{1}$, MPH; Margarita Calvo Armijo ${ }^{1}$, BSN, MA, PhD

\footnotetext{
${ }^{1}$ Cizik School of Nursing, University of Texas Health Science Center at Houston, Houston, TX, United States

${ }^{2}$ Center for AIDS Prevention Studies and UCSF Prevention Research Center, University of California San Francisco, San Francisco, CA, United States

${ }^{3}$ Sue \& Bill Gross School of Nursing, University of California Irvine, Irvine, CA, United States

${ }^{4}$ TSET Health Promotion Research Center, University of Oklahoma Health Sciences Center, Oklahoma City, OK, United States

${ }^{5}$ Baylor College of Medicine, Houston, TX, United States

${ }^{6}$ Department of Family and Community Medicine, Baylor College of Medicine, Houston, TX, United States
}

\section{Corresponding Author:}

Diane Santa Maria, BSN, MSN, DrPH

Cizik School of Nursing

University of Texas Health Science Center at Houston

6901 Bertner Ave

Houston, TX, 77030

United States

Phone: 17135002190

Email: diane.m.santamaria@uth.tmc.edu

\section{Abstract}

Background: Youth experiencing homelessness are more likely than housed youth to experience premature death, suicide, drug overdose, pregnancy, substance use, and mental illness. Yet while youth experiencing homelessness are 6 to 12 times more likely to become infected with HIV than housed youth, with HIV prevalence as high as $16 \%$, many do not access the prevention services they need. Despite adversities, youth experiencing homelessness are interested in health promotion programs, can be recruited and retained in interventions and research studies, and demonstrate improved outcomes when programs are tailored and relevant to them.

Objective: The study aims to compare the efficacy of a nurse case management HIV prevention and care intervention, titled Come As You Are, with that of usual care among youth experiencing homelessness aged 16 to 25 years.

Methods: The study is designed as a 2-armed randomized wait-list controlled trial. Participants ( $\mathrm{n}=450)$ will be recruited and followed up for 9 months after the intervention for a total study period of 12 months. Come As You Are combines nurse case management with a smartphone-based daily ecological momentary assessment to develop participant-driven HIV prevention behavioral goals that can be monitored in real-time. Youth in the city of Houston, Texas will be recruited from drop-in centers, shelters, street outreach programs, youth-serving organizations, and clinics.

Results: Institutional review board approval (Committee for the Protection of Human Subjects, University of Texas Health Science Center at Houston) was obtained in November 2018. The first participant was enrolled in November 2019. Data collection is ongoing. To date, 123 participants have consented to participate in the study, 89 have been enrolled, and 15 have completed their final follow-up.

Conclusions: There is a paucity of HIV prevention research regarding youth experiencing homelessness. Novel and scalable interventions that address the full continuum of behavioral and biomedical HIV prevention are needed. This study will determine whether a personalized and mobile HIV prevention approach can reduce HIV risk among a hard-to-reach, transient population of youth at high risk.

International Registered Report Identifier (IRRID)： DERR1-10.2196/26716 
(JMIR Res Protoc 2021;10(5):e26716) doi: 10.2196/26716

\section{KEYWORDS}

HIV prevention; nurse case management; motivational interviewing; homelessness; youth; just-in-time-adaptive intervention; ecological momentary assessment

\section{Introduction}

\section{HIV Risks Among Youth Experiencing Homelessness}

A number of systemic barriers and risk behaviors drive high HIV infection rates among youth experiencing homelessness. Youth experiencing homelessness have earlier sexual debuts; are more likely to have multiple sexual partners; and trade sex for food, shelter, money, drugs, or alcohol [1,2]. They are more likely to use substances before sex, are less likely to use condoms, and are overrepresented by youth who identify as men who have sex with men; each of these characteristics increase risk for HIV [3,4], and those who trade sex are at high risk for HIV infection as they are rarely able to negotiate condom use due to the power dynamics [5] and often lack knowledge about biomedical advances in HIV prevention such as preexposure prophylaxis and nonoccupational postexposure prophylaxis [6]. In a recent 7-city (Houston, Denver, St. Louis, Phoenix, Los Angeles, San Jose, New York City) study of 1427 youth experiencing homelessness (58\% male, $81 \%$ youth of color, $31 \%$ lesbian, gay, bisexual, transgender, queer [LGBTQ]), $71 \%$ of participants had little to no knowledge of preexposure prophylaxis [7]. Reassuringly, 53\% of study participants had undergone HIV testing in the preceding 3 months [7]. Unfortunately, youth experiencing homelessness experience sexual assault and forced sex at high rates $(22 \%$ and $24 \%$ respectively); yet only $29 \%$ received a postsexual assault examination which is when they could have received nonoccupational postexposure prophylaxis and sexually transmitted infection (STI) treatment [8]. The Society for Adolescent Health and Medicine has recommended the development of screening tools, skill-building interventions, and accessible preexposure prophylaxis delivery models for all youth and young adults, particularly those experiencing disparities [9].

\section{Implications of Mental Health and Substance Use on HIV Risk}

HIV risk among youth experiencing homelessness is further exacerbated by multiple comorbid conditions, including mental illness and substance use. Suicide is one of the leading causes of death among youth experiencing homelessness [10], with suicide attempt rates ranging from $12 \%$ to $48 \%$ [11-13]. Rates of depression and posttraumatic stress among youth experiencing homelessness vary across studies with ranges from $8 \%$ [14] to $61 \%$ [15] and 5\% to $48 \%$ [16-18], respectively. A recent study [19] found that $42 \%$ of youth experiencing homelessness reported being moderately to severely stressed, $48 \%$ experienced mental distress, $48 \%$ had depression, and $23 \%$ had posttraumatic stress. Depression among youth experiencing homelessness may be due to a lifetime of adversity, abuse, neglect, and housing instability [20,21] —all of which can lead to inhibition and riskier sexual decision making and behavior [22]. Furthermore, rates of substance use are twice those of housed youth [3,23]. In one study [24], $86 \%$ of youth experiencing homelessness $(n=173)$ met the Diagnostic and Statistical Manual of Mental Disorders, fourth edition, criteria for a substance use disorder compared with only $14.2 \%$ in the general young adult population [25]; drug overdose is a leading cause of death among youth experiencing homelessness [10]. HIV prevention efforts should address mental health and the intersection of substance use and sexual behaviors.

\section{Barriers to Health Care Access}

Youth experiencing homelessness are underserved by the health care system for several reasons. Structural barriers include transportation, lack of health insurance, and costs [26]. Youth also suggest that fear of or past experiences of being judged, dismissed, or discriminated against by health care professionals reduce utilization [27]. Other barriers to health care access include fear of social service agency notification or legal intervention, lack of familiarity with health care resources, and lack of affordability [28]. As a result, youth experiencing homelessness often interact with the health care system at lower rates than their housed peers and frequently overutilize emergency departments for care while experiencing reduced access to prevention services [3]. Therefore, it is essential to increase access to and availability of HIV prevention services, and these services should be colocated with other service programs to foster trust and increase accessibility for youth experiencing homelessness [29-31]

\section{Interventions for Youth Experiencing Homelessness}

A recent systematic review [32] of interventions to prevent HIV among youth experiencing homelessness highlighted the paucity of HIV prevention research and concluded that more research is necessary. Interventions for youth experiencing homelessness should include the full continuum of behavioral and biomedical HIV prevention, including HIV and STI screening and treatment, preexposure prophylaxis, and nonoccupational postexposure prophylaxis [33]. Engagement in these prevention services requires interventions to increase preexposure prophylaxis awareness, screen for preexposure prophylaxis eligibility, promote condom use, provide assistance with health care navigation that includes care for mental health and substance use issues [34], and address transportation and health insurance challenges. Individuals impacted by mental illness, homelessness, and substance use have greater preexposure prophylaxis uptake and adherence when these abovementioned issues are also addressed [35]. Nurse case management is an evidence-based strategy that has been effective in addressing the multifaceted and complex health and social challenges of HIV prevention among youth experiencing homelessness [27,36-38]

\section{Nurse Case Management}

A nurse-led intervention allows for multiple HIV prevention services to be delivered during a single visit (eg, preexposure 
prophylaxis, nonoccupational postexposure prophylaxis, lab draws, STI testing and treatment), which may increase adherence. This is particularly important as being homeless can decrease effectiveness of linkages to care [39] as opposed to providing that care at the point of contact. Nurse case management has been efficacious in reducing drug use among methadone users [40] and youth experiencing homelessness [41], improving hepatitis $B$ vaccination rates [42], and facilitating HIV care coordination [43]. This comprehensive approach of simultaneously addressing concomitant problems (eg, mental health, substance use, and housing needs), incorporating the full continuum of behavioral and biomedical HIV prevention, is a promising strategy for engaging youth experiencing homelessness in HIV prevention. Given the widespread integration of nurses into current HIV programs serving youth experiencing homelessness, nurse-led interventions are likely scalable and can be integrated into existing HIV prevention programs.

To further engage youth experiencing homelessness, they should be met "where they are" [35] and interventions should be implemented in collaboration with existing health and social service providers by colocating the study activities at drop-in centers, shelters, and service providers that are highly used by youth experiencing homelessness. This strategy is particularly important given that past-month use of a drop-in center has been shown to predict HIV and STI testing [44], increase service utilization, and improve HIV-related outcomes [31]. These findings support the potential of delivering HIV prevention in drop-in centers and shelters to connect youth experiencing homelessness to other underutilizing services and health care. Moreover, drop-in centers may be a preferred HIV prevention service location of youth experiencing homelessness [31]. By integrating the delivery of HIV risk reduction interventions into already-established social services, we may enhance HIV prevention, increase retention, and improve access to mental health, substance use, and housing services.

\section{Motivational Interviewing and Behavior Feedback}

Nurse-led interventions can also integrate evidence-based strategies that have proven effective in increasing motivations for behavior change. Increasing motivation is particularly important for populations that are potentially overwhelmed by multifaceted and complex health and social challenges. Motivational interviewing is a person-centered counseling style that aims to strengthen a person's motivation and commitment to change and addresses ambivalence about behavior change [45]. Motivational interviewing has been successfully used with youth to improve uptake of and adherence to health behaviors resulting in reduced alcohol [46] and substance use [47], and increased condom [48] and contraceptive use [49]. Youth experiencing homelessness are self-reliant, can be challenging to engage, and may be distrustful of adults due to past trauma and victimization on the streets [50,51]. Motivational interviewing strategies can strengthen the relationship between the youth experiencing homelessness and providers to evoke participant driven HIV prevention goals [52].

Behavioral feedback technology might also increase motivation to change behavior as tailored and targeted feedback could further engage youth experiencing homelessness. Smartphone-based daily ecological momentary assessments have been used with youth experiencing homelessness. Instant feedback enhances cognitive appraisal of health-seeking and coping behaviors and increases motivation in youth experiencing homelessness [52,53]. Like many adolescents and young adults, youth experiencing homelessness underestimate their HIV risk [7], suggesting that self-monitoring may assist in aligning their behaviors with their perceived HIV risk. Immediate self-monitored behavioral feedback has been found to increase condom use [52,54]. A high number of youth have phones, and young adults, in general [55-57], and youth experiencing homelessness, specifically, have a preference to use technology [58]. A review [59] of 42 studies showed high ecological momentary assessments completion rates (78\%) among youth. Prior studies [60] have found similar high adherence rates (82\%-87\%) with homeless and vulnerable populations.

\section{Objectives}

This study describes the design and implementation of a nurse case management intervention (Come As You Are) efficacy trial with youth experiencing homelessness aged 16 to 25 years who received the active intervention or usual care. The intervention aims to increase uptake of HIV prevention strategies (eg, pre- and postexposure prophylaxis uptake, HIV testing, STI screening and treatment, sober sex, and condom use) when compared with usual care youth experiencing homelessness immediately postintervention and 3, 6, and 9 months postintervention. The study also aims to determine whether the intervention improves mental health symptoms, substance use, and housing status. Additionally, we will assess whether health seeking, coping, HIV risk perception, pre- and postexposure prophylaxis barriers and facilitators, and condom self-efficacy mediate the effect of the intervention on uptake prophylaxis, condom use, and HIV/STI testing. This protocol paper describes the study design, intervention, recruitment, and retention strategies.

\section{Methods}

\section{Study Design}

This study uses a 2-armed randomized controlled trial design with a wait-list control group to determine the efficacy of the intervention compared to usual care. The primary outcomes are the uptake of HIV prevention strategies (preexposure prophylaxis and nonoccupational postexposure prophylaxis, HIV and STI testing, and condom use). Secondary outcomes of the intervention include the impact on mental health, substance use, and housing status. Follow-up surveys are conducted immediately after the 3-month intervention period and 3, 6, and 9 months postintervention (Figure 1).

Participants are randomly assigned to the intervention or wait-list control arm using a computer-generated blocked 2:1 allocation. By the end of the recruitment period, we anticipate that 300 participants will be randomized to the intervention arm and 150 randomized to the wait-list control arm. Participants are informed in which group they are allocated after completing the baseline survey. 
Figure 1. Study flow diagram. CAYA: Come As You Are.

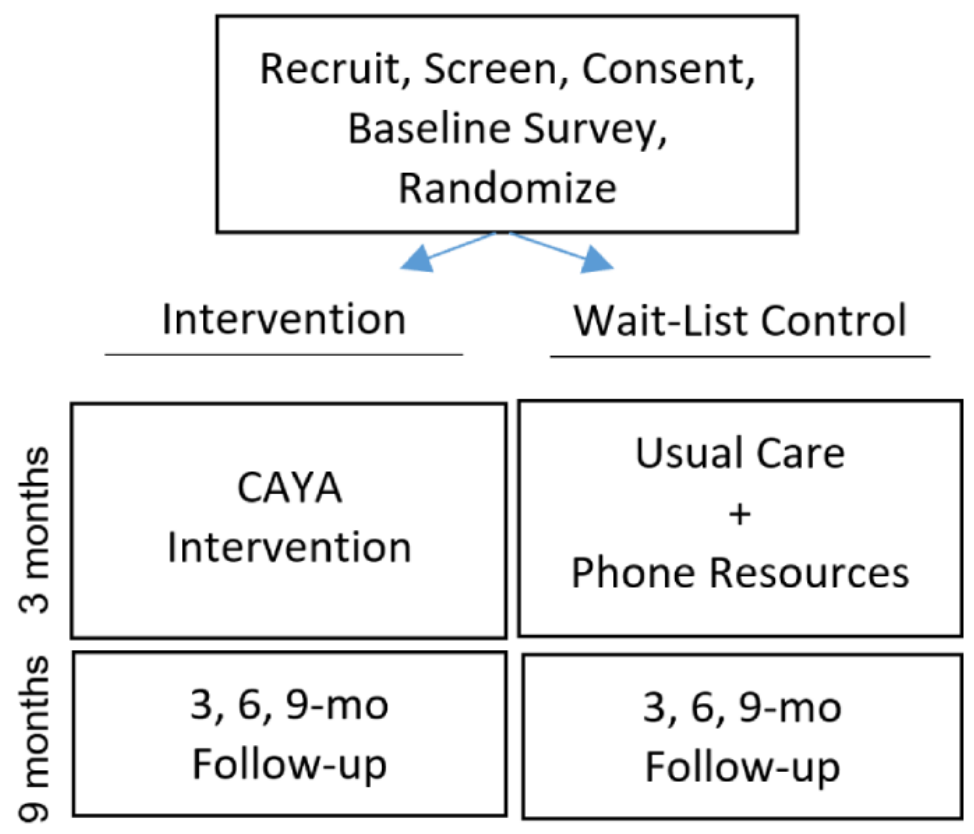

\section{Recruitment}

Utilizing numerous recruitment sites in Houston-drop-in centers, shelters, local youth experiencing homelessness service locations, clinics, federally qualified health care centers in locations with a high concentration of homelessness, magnet (eg, hot meal) events, mobile clinics, and street outreach-will increase generalizability of the findings by including a sample of both connected and disconnected youth experiencing homelessness. These recruitment sites serve young men, women, families, and LGBTQ youth. We make use of group-based study introduction sessions, flyers, and recruitment letters at the agencies, clinics, street outreach, and the website and Facebook pages of the agencies and Homeless Youth Network of Houston. We have used these methods successfully in previous studies [61]. The research staff will maintain a consistent, weekly presence at the recruitment sites throughout the study to facilitate both recruitment and follow-up efforts. In response to COVID-19 physical distancing requirements and shelter closures, we are also using snowballing participant referral techniques and online advertisements.

\section{Inclusion and Exclusion Criteria}

Our sample is limited to youth, 16 to 25 years old, to align with youth homelessness services providers and adolescent risk behavior studies [7], current guidelines for preexposure prophylaxis and nonoccupational postexposure prophylaxis use $[62,63]$, and evidence that experiencing homelessness as a young adult under 26 years of age is associated with heightened sexual risk behaviors and substance use [33]. Individuals are eligible to be included if they (1) are 16 to 25 years old, (2) speak English, (3) are experiencing homelessness, and (4) are not planning to move out of the Houston metropolitan area during the study.

Experiencing homelessness is defined as having slept on the streets, in a place not meant for habitation, in a shelter, hotel or motel, or with someone where they cannot stay for more than
30 days (eg, couch surfing). Youth experiencing homelessness may stay in emergency shelters or on the streets (eg, parks and tent cities); in abandoned or vacant buildings or apartments; temporarily with friends, family, or acquaintances; or in rented hotel or motel rooms [35], and they can go to great lengths to stay hidden from the dangers of victimization [50]. This broad definition of homelessness aligns with the McKinney-Vento Homeless Assistance Act of 1987 [64], which allows us to account for the transiency and instability of housing experienced by youth experiencing homelessness and increases the generalizability of the study findings.

Youth with very low literacy (Rapid Estimate of Adult Literacy in Medicine-Short Form [65] health literacy assessment score <4)[1] are excluded from the study due to the need to independently read the daily smartphone-based assessments. Additionally, youth who are noticeably intoxicated or experiencing acute mental distress are encouraged to be screened for enrollment at a later time to assure safety and acute needs are met prior to enrollment. Youth are connected to services at the recruitment sites for acute needs.

\section{Study Enrollment}

Due to the transient nature of the study population, study participants are being enrolled in a stepwise process that takes place over the course of 3 weeks. The first step entails a thorough review of the consent form and collection of contact information including a photo, and the second step consists of baseline data collection. During the third step, participants receive the study phone and are notified of study group assignment. Intervention participants receive the first intervention session on the same day that they receive the study phone. During the COVID-19 pandemic, consenting and the baseline survey are being completed remotely as needed to reduce the face-to-face study visits to only 1 enrollment visit. 


\section{Intervention Description}

The Come As You Are intervention is based on the Comprehensive Health Seeking and Coping Framework (CHSCF; Figure 2), which describes how the nurse and client work together to mutually develop goals and strategies to improve health in a context of nonjudgmental acceptance. Accomplishment of goals occur by addressing cognitive appraisals (clarifying misconceptions), promoting health seeking, and addressing knowledge and coping behaviors that incorporate the situational, personal, social, and resource needs affecting health. The intervention involves coordinated, individualized, comprehensive care delivered by a nurse that includes a comprehensive health assessment, mutual care plan development, prevention education, and health and social service navigation [36-38,41]. An individualized, rather than group based, intervention was chosen for this study due to the heterogeneity of youth experiencing homelessness and their risk behaviors and the challenges associated with group session designs, including low attendance [66]. The intervention has 2 main components: 6 face-to-face sessions with a study nurse and a behavioral assessment and feedback app. Additionally, booster calls are made monthly for 3 months following the last face-to-face session. This intervention is guided by the CHSCF [67] and uses motivational interviewing [45,68] strategies to promote behavior change and uptake of HIV prevention strategies by facilitating goal setting and evoking change talk.

Figure 2. Motivational interviewing enhanced case management. CAYA: Come As You Are; HIV: human immunodeficiency virus; PrEP: preexposure prophylaxis; nPEP: nonoccupational postexposure prophylaxis; STI: sexually transmitted infection.

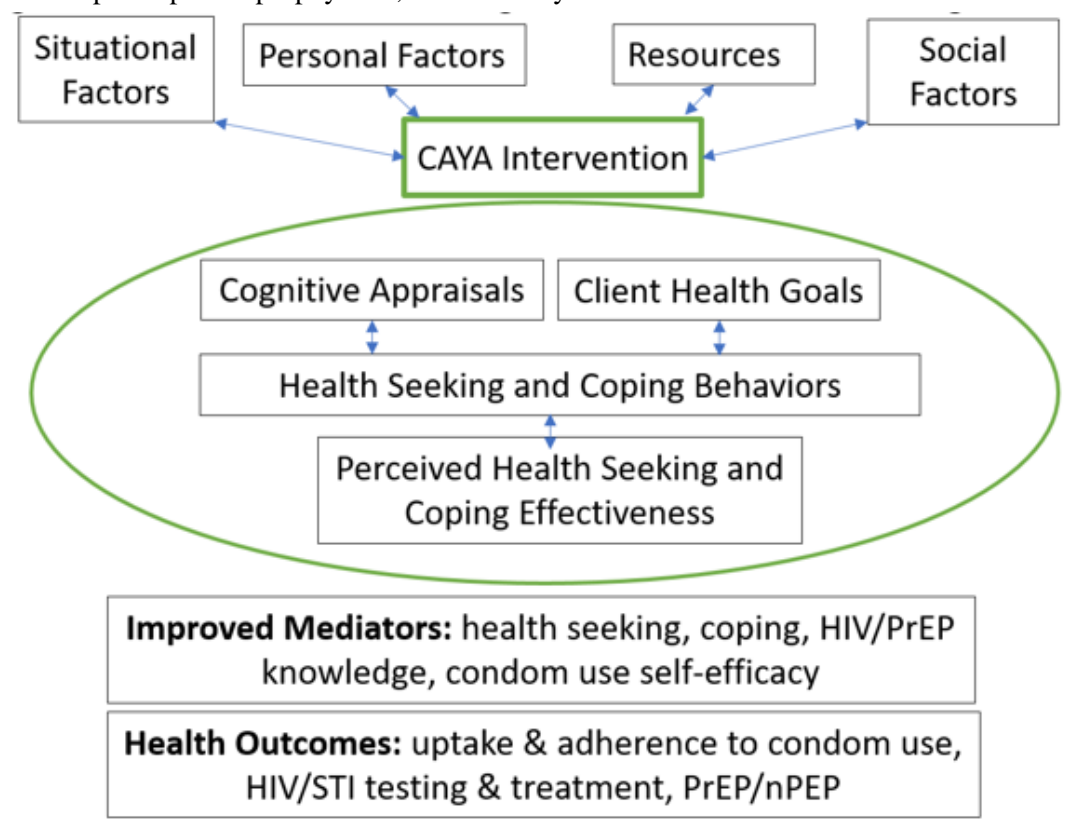

\section{Come As You Are Intervention Group}

\section{Face-to-Face Sessions}

The 6 biweekly 1-hour face-to-face sessions are designed to meet the complex, individual, multilevel health and social needs of homeless youth to align with extant literature demonstrating the strong connection between HIV risk behaviors and mental health, substance use, and housing [69]. During each session, the nurse uses motivational interviewing strategies to assess current mental health, substance use, and housing needs to establish a plan of care to assist youth in generating HIV prevention behavioral goals while addressing barriers. During these sessions, the nurse conducts an HIV risk profile and preexposure prophylaxis eligibility assessment and guides discussions about goal attainment strategies (Table 1). Six sessions allow for the development of the nurse-client relationship and for adequate time to establish, monitor, and maintain HIV prevention goals [70]. The motivational interviewing strategies allow the sessions to be youth-driven and tailored to the individual's needs based on their current HIV risk behaviors, HIV status, behavioral goals, and motivation level. In response to the challenges experienced during the COVID-19 pandemic, the nurses also offered to conduct these individual sessions via videochat or phone call as needed (when shelter-in-place orders are enacted or service sites are closed) to protect their clients. 
Table 1. Come As You Are session description.

\begin{tabular}{|c|c|c|c|c|}
\hline Number & Session title & $\mathrm{CHSCF}^{\mathrm{a}}$ constructs & Discussion topics & Session goals \\
\hline 1 & $\begin{array}{l}\text { Introduction and } \\
\text { needs assessment }\end{array}$ & $\begin{array}{l}\text { Situational, personal, so- } \\
\text { cial factors, and resources }\end{array}$ & $\begin{array}{l}\text { Review } \mathrm{HIV}^{\mathrm{b}} \text { risk behavior and prevention strategy } \\
\text { (condoms, HIV/STI }{ }^{\mathrm{c}} \text { testing, treatment, preexposure } \\
\text { prophylaxis, nonoccupational postexposure prophylaxis) } \\
\text { knowledge, attitudes, beliefs, and self-efficacy }\end{array}$ & $\begin{array}{l}\text { Establish rapport; assess } \\
\text { HIV risk, preexposure } \\
\text { prophylaxis eligibility }\end{array}$ \\
\hline 2 & $\begin{array}{l}\text { HIV prevention } \\
\text { strategies and goal } \\
\text { setting }\end{array}$ & Nursing goals & $\begin{array}{l}\text { Review personal HIV risk; use motivational interviewing } \\
\text { to discuss risk reduction and prevention strategies; evoke } \\
\text { change talk }\end{array}$ & $\begin{array}{l}\text { Select HIV prevention } \\
\text { goals and action plan }\end{array}$ \\
\hline 3 & $\begin{array}{l}\text { Behavioral feedback } \\
\text { and goal alignment }\end{array}$ & $\begin{array}{l}\text { Health seeking and coping } \\
\text { behaviors }\end{array}$ & $\begin{array}{l}\text { Identify gaps between goals and behaviors (eg, self- } \\
\text { management, coping, health care engagement); evoke } \\
\text { change talk }\end{array}$ & $\begin{array}{l}\text { Revise/reinforce plan to } \\
\text { meet/maintain HIV preven- } \\
\text { tion goals }\end{array}$ \\
\hline 4 & $\begin{array}{l}\text { Addressing facilita- } \\
\text { tors and barriers }\end{array}$ & $\begin{array}{l}\text { Perceived behavior adher- } \\
\text { ence and coping effective- } \\
\text { ness }\end{array}$ & $\begin{array}{l}\text { Review goals and action plan; use motivational interview- } \\
\text { ing to discuss personal HIV prevention behavior change } \\
\text { facilitators and barriers; evoke change talk }\end{array}$ & $\begin{array}{l}\text { Revise/reinforce HIV pre- } \\
\text { vention goals and action } \\
\text { plan to increase facilitators }\end{array}$ \\
\hline 5 & $\begin{array}{l}\text { Establishing a medi- } \\
\text { cal home }\end{array}$ & $\begin{array}{l}\text { Immediate health out- } \\
\text { comes }\end{array}$ & $\begin{array}{l}\text { Review goals and action plan; discuss local clinic prefer- } \\
\text { ences and schedule well-check as indicated; evoke change } \\
\text { talk and behavioral maintenance }\end{array}$ & $\begin{array}{l}\text { Revise/reinforce HIV pre- } \\
\text { vention goals, action plan, } \\
\text { follow-up care plan }\end{array}$ \\
\hline 6 & $\begin{array}{l}\text { Moving toward } \\
\text { health and wellbeing }\end{array}$ & $\begin{array}{l}\text { Long-term health out- } \\
\text { comes }\end{array}$ & $\begin{array}{l}\text { Review goals and action plan; identify additional health, } \\
\text { housing, work, and education needs and goals; evoke } \\
\text { change talk and behavioral maintenance plans }\end{array}$ & $\begin{array}{l}\text { Reinforce HIV prevention } \\
\text { goals and action plan }\end{array}$ \\
\hline
\end{tabular}

${ }^{\mathrm{a} C H C S F}$ : Comprehensive Health Seeking and Coping Framework.

${ }^{b}$ HIV: human immunodeficiency virus.

${ }^{\mathrm{c}} \mathrm{STI}$ : sexually transmitted infections.

\section{HIV Risk Profile and Preexposure Prophylaxis Eligibility Assessment}

HIV status is assessed at baseline using a rapid, finger stick HIV test. During the first intervention session and at the beginning of each subsequent session, the nurse uses a screening tool developed from the Centers for Disease Control and Prevention 2014 Clinical Practice Guidelines to assess preexposure prophylaxis eligibility. This screener is used to assess preexposure prophylaxis eligibility based on the participants' HIV risk behaviors (eg, having an HIV-positive sexual partner, a recent bacterial STI, number of sex partners, a history of inconsistent or no condom use, injection drug use, or trade sex) to determine whether recent behaviors warrant preexposure prophylaxis as a possible intervention for HIV prevention. preexposure prophylaxis and HIV clinical care guidelines and standing orders under the supervision of a health care provider are incorporated into the 6 nurse sessions. The care plan for these participants includes coordinating access to, uptake of, and adherence to preexposure prophylaxis, and promoting HIV-preventing behaviors (eg, HIV/STI testing, using condoms, reducing sexual partners, reducing intravenous drug use, engaging in sober sex, and avoiding trade sex). When a youth is HIV-negative and preexposure prophylaxis-eligible, the nurse discusses what preexposure prophylaxis is, how it works, its risks and benefits, and the implications of its use (eg, follow-up lab work and appointment schedule) to promote shared decision making. When participants are interested in receiving preexposure prophylaxis, the nurse works with the preexposure prophylaxis navigator who accompanies the youth to the preexposure prophylaxis appointment to begin lab work and assists with completing an application form to cover preexposure prophylaxis medication costs.

\section{HIV Prevention Goal Setting}

The nurse uses motivational interviewing strategies to evoke youth-driven HIV prevention goals and behavior change talk. Each session includes personalized HIV prevention education (ie, personal risk behaviors and prevention strategies) and goal setting. Session appraisals help align the youth's goals with their current behaviors and evoke personal motivation to adopt and maintain HIV prevention strategies. For youth who are not preexposure prophylaxis-eligible, the nurse promotes the adoption or maintenance of other HIV prevention strategies (ie, condom use).

\section{Behavioral Interface}

Building on the goal setting, participants in the intervention group complete a brief, daily ecological momentary assessment on their study-issued phone during the 3-month intervention delivery period. The ecological momentary assessment asks about sexual risk behaviors, sexual urges, stress, affect, social interactions, coping, and circumstances from the prior day (eg, where did you stay last night, sexual activity, substance use), and it takes less than 5 minutes to complete. Once the daily ecological momentary assessment is completed, the data populate a behavioral goal interface accessible by password on the study-issued smartphone (Figure 3). This interface provides a visual display based on the participant's HIV prevention goals, and their behaviors as reported in the daily ecological momentary assessment. It allows the nurse and youth to review how current behaviors align with the health goals established during the Come As You Are session and facilitates discussion 
Figure 3. Example behavioral interface.

\section{Insight}

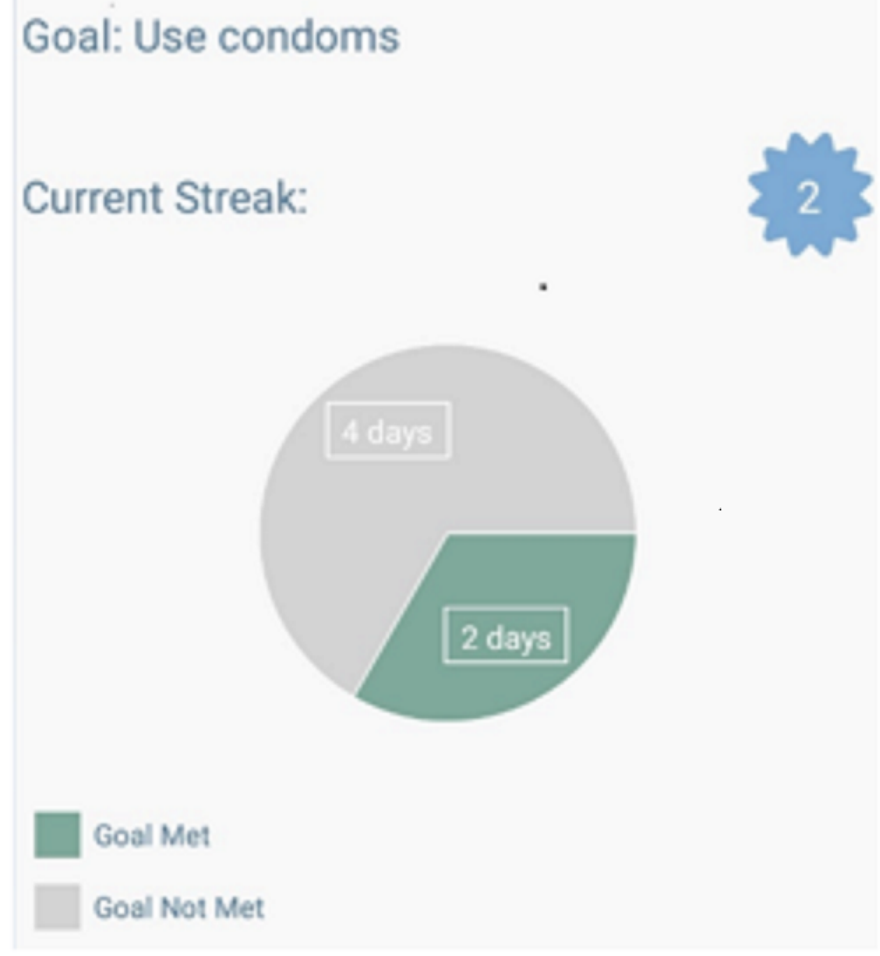

\section{Booster Calls}

After the face-to-face intervention sessions are completed, the team makes monthly booster calls to intervention participants on the study-issued phone for 3 months following the end of the individual sessions. During these calls, the team members inquire about the uptake and adherence to the HIV prevention strategies outlined during the Come As You Are sessions, asks if there are any other needs that they can address for the participant at that time, and helps the participant access and navigate services (ie, shelters, mental health counseling, health care) as needed.

\section{Wait-list Control Group}

Youth in the control condition receive usual care from the recruitment sites including assistance with housing, food and clothing needs; basic health assessments and health care; limited anticipatory guidance; access to mental health counseling; substance use treatment referrals; and preexposure prophylaxis or nonoccupational postexposure prophylaxis referrals. Youth receiving usual care also receive a study phone and complete the baseline, 3-, 6-, and 9-month follow-up surveys. After the 12-month study period is completed, youth in the control group are invited to access the full Come As You Are intervention.

A Community Advisory Group and Youth Working Group provided input on study procedures, protocol implementation and will be active in the interpretation and dissemination of the findings to the community. These groups assisted in the development of study procedures, survey items, and recruitment materials. Additionally, they oversaw the creation of a local homeless resource guide to be given to all participants at the time of enrollment and preprogrammed into the study-issued phones. This guide contains location and contact information for local shelters, meals, social, legal, and education services, and clinics. These resources are available in paper version and preloaded to the phones (ie, suicide hotline, shelter contacts) for all participants. The Community Advisory Group are current service providers for youth experiencing homelessness. The Youth Working Group members are youth with lived homelessness experiences between the ages of 18 to 25 years.

\section{Data Collection Procedures}

Data collected include baseline and follow-up survey data, HIV and STI test data, and data from smartphone-based daily ecological momentary assessments. Assessments are collected at baseline, at the end of treatment ( 3 months postbaseline), and 3, 6, and 9 months postintervention using REDCap (Vanderbilt University). The surveys are done in person or through a link to the survey sent to the participant via text message or email. The baseline survey assesses demographics (eg, age when first experiencing homelessness, duration experiencing homelessness, race and ethnicity, sexual orientation, gender identity), psychosocial factors, sexual behaviors, substance use, and mental health. The end of treatment assessment for the intervention group contains intervention process outcome items including what participants found to be the most and the least helpful, what made it easy or difficult to attend sessions. HIV and STI test data are collected at baseline, at the end of treatment, and 3, 6, and 9 months postintervention. Table 2 
outlines measures used for primary outcomes. Youth with a positive STI test receives treatment and care coordination from the Healthcare for the Homeless Houston program, shelter clinics, or their medical home when preferred. Youth who test positive for HIV during the study will be linked to HIV care at a local clinic by the nurse.

Table 2. Outcome measures.

\begin{tabular}{|c|c|c|}
\hline Construct & Scale or measure & Cronbach $\alpha$ \\
\hline \multicolumn{3}{|l|}{ Aim 1 outcomes } \\
\hline Prophylaxis uptake & $\begin{array}{l}\text { Preexposure prophylaxis uptake; nonoccupational postexposure } \\
\text { prophylaxis uptake (NCM report, chart review) }\end{array}$ & $-^{\mathrm{a}}$ \\
\hline Condom use & $\begin{array}{l}\text { Youth Risk Behavior Survey [71] (condom use at last sexual } \\
\text { encounter) }\end{array}$ & - \\
\hline $\mathrm{HIV}^{\mathrm{b}} / \mathrm{STI}^{\mathrm{c}}$ test uptake & Rapid HIV test; gonorrhea, chlamydia, syphilis tests & - \\
\hline \multicolumn{3}{|l|}{ Aim 2 outcomes } \\
\hline Mental health & Kessler Psychological Distress Scale $[72,73]$ & - \\
\hline Housing status & In a shelter, apt/house, with someone, outside, in a car & - \\
\hline Substance use & Texas Christian University Drug Screen II $[74,75]$ & .89 \\
\hline \multicolumn{3}{|l|}{ Exploratory outcomes $^{d}$} \\
\hline Health care engagement & Health care utilization, Medical Mistrust Index 2.1 [76] & - \\
\hline Condom-use self-efficacy & Condom Control beliefs [77] & $.74-.83$ \\
\hline HIV risk perception & Perceived Risk of HIV scale [78] & .88 \\
\hline Preexposure prophylaxis facilitators and barriers & Facilitators and Barriers to Preexposure Prophylaxis Use [79] & - \\
\hline Health seeking & General Help Seeking Questionnaire [80] & .83 \\
\hline Coping & Derived from Ways of Coping Questionnaire [81] & - \\
\hline
\end{tabular}

${ }^{\mathrm{a}}$ No data.

${ }^{\mathrm{b}} \mathrm{HIV}$ : human immunodeficiency virus.

${ }^{\mathrm{c}}$ STI: sexually transmitted infections.

${ }^{\mathrm{d}}$ Possible mediators based on Comprehensive Health Seeking and Coping Framework.

For HIV testing, we use the INSTI HIV-1/HIV-2 Rapid Antibody Test $(99.5 \%$ sensitivity, $100 \%$ specificity; Biolytical Laboratories Inc)[82]. Urine specimens are collected and transported on the same day to a local clinic to test for Chlamydia trachomatis and gonorrhea (Neisseria gonorrhoeae), and results are shared with participants via phone call or in person. Blood samples are tested for syphilis (Treponema pallidum) using an antibody rapid immunochromatographic test (Syphilis Health Check, Trinity Biotech plc)[83]. Due to restrictions on in-person study visits during the COVID-19 pandemic, additional options for STI testing, including going to conveniently located partner clinics or receiving an at-home STI testing kits, are being provided to study participants as attrition mitigation strategies.

\section{Results}

Institutional review board approval (Committee for the Protection of Human Subjects HSC-SN-18-0993) was obtained in November 2018. The first participant was enrolled in November 2019. Data collection is ongoing - to date, 130 participants have consented to the study, 110 have enrolled, and 15 have completed the final follow up-and expected to conclude in 2022.

\section{Discussion}

This study will provide essential data on the efficacy of a 2-component nurse case management HIV prevention intervention (ie, nursing visits and smartphone based behavioral monitoring and feedback) among youth experiencing homelessness. Findings from the study will significantly contribute to the field of HIV prevention in a marginalized and hard-to-reach population. The intervention is designed to be scalable within the practical parameters of care currently provided through the Health care for the Homeless programs across the nation.

This project is innovative in several ways. It addresses the underutilized role of nurses, the most trusted professionals in the United States [84], in the HIV prevention team. Consequently, nurses' abilities to provide HIV prevention services may reduce the need to refer youth experiencing homelessness to other health care providers, which can decrease referral no-show and treatment plan nonadherence. Combining nurse case management with motivational interviewing and behavioral feedback can potentiate motivation for adopting HIV prevention behaviors and address the full continuum of behavioral and biomedical HIV prevention with youth experiencing homelessness. If found to be effective, this 
intervention can be applied to improve existing youth experiencing homelessness HIV prevention program, maximizing the available resources and potential outcomes.

The eponymous intervention capitalizes on the "come as you are" approach endorsed in clinical guidelines [85] put forth by the National Healthcare for the Homeless Council and aligns with NIH and Ending the HIV Epidemic High Priority areas [86] for reducing HIV through behavioral prevention and access to services in high HIV prevalence and substance-using, high-risk populations. Additionally, the intervention facilitates coordination with youth experiencing homelessness service providers to meet mental health, substance use, and housing service needs and connects youth to the health care services, such as HIV and STI testing and treatment.

The potential benefits of study participation include increased knowledge about HIV transmission and increased uptake of prevention strategies. Participants may become more aware of how thoughts and feelings can affect one's behaviors and improve uptake and adhere to HIV prevention goals. Research staff are provided with comprehensive lists of resources available to youth experiencing homelessness and receive extensive training on how to make referrals to appropriate resources if a participant indicates that they need services they are not otherwise receiving. Participants will have access to resources and contact information for services that will be preprogrammed into the study-issued smartphones provided to all participants throughout the duration of the study. Participants in the intervention arm may also benefit from linkages to care provided through the Come As You Are intervention. Through the HIV and STI testing offered to all participants, youth may become aware of a positive result and receive necessary treatment and linkages to care that they may not have otherwise received. If efficacious, this scalable intervention has the potential to be disseminated to young people experiencing homelessness across the country without requiring significant investments in infrastructure, equipment, or staff resources. Some potential challenges related to whether youth have access to a phone are present, though studies suggest that smartphone use among youth experiencing homelessness is similar to that in the general population, ranging from $47 \%$ to $78 \%$ [87,88]. Given the implementation of this study during the COVID-19 pandemic, there are unique learning opportunities related to executing a randomized control trial focused on HIV prevention during a global pandemic with youth experiencing homelessness.

\section{Conflicts of Interest}

MB is the primary inventor of the Insight mHealth Platform that was used to collect data for this study. MB receives royalties when researchers outside his home institution use this software.

\section{References}

1. Beech BM, Myers L, Beech DJ, Kernick NS. Human immunodeficiency syndrome and hepatitis B and C infections among homeless adolescents. Semin Pediatr Infect Dis 2003 Jan;14(1):12-19. [doi: 10.1053/spid.2003.127212] [Medline: 12748917]

2. Gangamma R, Slesnick N, Toviessi P, Serovich J. Comparison of HIV risks among gay, lesbian, bisexual and heterosexual homeless youth. J Youth Adolesc 2008 Feb 24;37(4):456-464 [FREE Full text] [doi: 10.1007/s10964-007-9171-9] [Medline: 18607514]

3. Edidin JP, Ganim Z, Hunter SJ, Karnik NS. The mental and physical health of homeless youth: a literature review. Child Psychiatry Hum Dev 2012 Jun 26;43(3):354-375. [doi: 10.1007/s10578-011-0270-1] [Medline: 22120422]

4. Thompson S, Pillai V. Determinants of runaway episodes among adolescents using crisis shelter services. Int J Soc Welf 2006 Apr 15;15(2):142-149. [doi: 10.1111/j.1468-2397.2006.00370.x]

5. Urada LA, Morisky DE, Pimentel-Simbulan N, Silverman JG, Strathdee SA. Condom negotiations among female sex workers in the Philippines: environmental influences. PLoS One 2012 Mar 20;7(3):e33282 [FREE Full text] [doi: 10.1371/journal.pone.0033282] [Medline: 22448241]

6. Smid M, Bourgois P, Auerswald C. The challenge of pregnancy among homeless youth: reclaiming a lost opportunity. $\mathrm{J}$ Health Care Poor Underserved 2010 May;21(2 Suppl):140-156 [FREE Full text] [doi: 10.1353/hpu.0.0318] [Medline: 20453382]

7. Santa Maria D, Flash C, Narendorf S, Barman-Adhikari A, Petering R, Hsu HT, et al. Knowledge and attitudes about pre-exposure prophylaxis among young adults experiencing homelessness in seven U.S. cities. J Adolesc Health 2019 May;64(5):574-580. [doi: 10.1016/j.jadohealth.2018.06.023] [Medline: 30254009]

8. Santa Maria D, Breeden K, Drake SA, Narendorf SC, Barman-Adhikari A, Petering R, et al. Gaps in sexual assault health care among homeless young adults. Am J Prev Med 2020 Feb;58(2):191-198 [FREE Full text] [doi:

10.1016/j.amepre.2019.09.023] [Medline: 31859174]

9. Society for Adolescent Health and Medicine. HIV pre-exposure prophylaxis medication for adolescents and young adults: a position paper of the society for adolescent health and medicine. J Adolesc Health 2018 Oct;63(4):513-516. [doi: 10.1016/j.jadohealth.2018.07.021] [Medline: 30286903]

10. Roy E, Haley N, Leclerc P, Sochanski B, Boudreau JF, Boivin JF. Mortality in a cohort of street youth in Montreal. JAMA 2004 Aug 04;292(5):569-574. [doi: 10.1001/jama.292.5.569] [Medline: 15292082]

11. Greene JM, Ringwalt CL. Youth and familial substance use's association with suicide attempts among runaway and homeless youth. Subst Use Misuse 1996 Jun 03;31(8):1041-1058. [doi: 10.3109/10826089609072286] [Medline: $\underline{806167]}$ 
12. Molnar BE, Shade SB, Kral AH, Booth RE, Watters JK. Suicidal behavior and sexual/physical abuse among street youth. Child Abuse \& Neglect 1998 Mar;22(3):213-222. [doi: 10.1016/s0145-2134(97)00137-3]

13. Noell JW, Ochs LM. Relationship of sexual orientation to substance use, suicidal ideation, suicide attempts, and other factors in a population of homeless adolescents. J Adolesc Health 2001 Jul;29(1):31-36. [doi: 10.1016/s1054-139x(01)00205-1] [Medline: 11429303]

14. Khurana S, Sharma N, Jena S, Saha R, Ingle GK. Mental health status of runaway adolescents. Indian J Pediatr 2004 May;71(5):405-409. [doi: 10.1007/bf02725627]

15. Votta E, Farrell S. Predictors of psychological adjustment among homeless and housed female youth. J Can Acad Child Adolesc Psychiatry 2009 May;18(2):126-132 [FREE Full text] [Medline: 19495433]

16. Slesnick N, Prestopnik J. Dual and multiple diagnosis among substance using runaway youth. Am J Drug Alcohol Abuse 2005;31(1):179-201 [FREE Full text] [doi: 10.1081/ada-200047916] [Medline: 15768577]

17. Bender K, Ferguson K, Thompson S, Komlo C, Pollio D. Factors associated with trauma and posttraumatic stress disorder among homeless youth in three U.S. cities: the importance of transience. J Trauma Stress 2010 Mar 09;23(1):161-168. [doi: 10.1002/jts.20501] [Medline: 20146399]

18. Whitbeck LB, Chen X, Hoyt DR, Tyler KA, Johnson KD. Mental disorder, subsistence strategies, and victimization among gay, lesbian, and bisexual homeless and runaway adolescents. J Sex Res 2004 Nov;41(4):329-342. [doi: 10.1080/00224490409552240] [Medline: 15765273]

19. Narendorf SC, Cross MB, Santa Maria D, Swank PR, Bordnick PS. Relations between mental health diagnoses, mental health treatment, and substance use in homeless youth. Drug Alcohol Depend 2017 Jun 01;175:1-8. [doi: 10.1016/j.drugalcdep.2017.01.028] [Medline: 28364629]

20. Kidd SA. Factors precipitating suicidality among homeless youth. Youth \& Society 2016 Aug 19;37(4):393-422. [doi: 10.1177/0044118x05282763]

21. Rew L, Taylor-Seehafer M, Thomas NY, Yockey RD. Correlates of resilience in homeless adolescents. J Nurs Scholarsh 2001 Mar;33(1):33-40. [doi: 10.1111/j.1547-5069.2001.00033.x] [Medline: 11253578]

22. Hall KS, Moreau C, Trussell J, Barber J. Role of young women's depression and stress symptoms in their weekly use and nonuse of contraceptive methods. J Adolesc Health 2013 Aug;53(2):241-248 [FREE Full text] [doi: 10.1016/j.jadohealth.2013.02.009] [Medline: 23582524]

23. Kulik D, Gaetz S, Crowe C, Ford-Jones EL. Homeless youth's overwhelming health burden: a review of the literature. Paediatr Child Health 2011 Jun;16(6):e43-e47 [FREE Full text] [doi: 10.1093/pch/16.6.e43] [Medline: 22654549]

24. Ginzler JA, Garrett SB, Baer JS, Peterson PL. Measurement of negative consequences of substance use in street youth: an expanded use of the Rutgers Alcohol Problem Index. Addict Behav 2007 Jul;32(7):1519-1525. [doi: 10.1016/j.addbeh.2006.11.004]

25. Grant BF, Saha TD, Ruan WJ, Goldstein RB, Chou SP, Jung J, et al. Epidemiology of DSM-5 drug use disorder:results from the National Epidemiologic Survey on Alcohol and Related Conditions-III. JAMA Psychiatry 2016 Jan;73(1):39-47 [FREE Full text] [doi: 10.1001/jamapsychiatry.2015.2132] [Medline: 26580136]

26. Chelvakumar G, Ford N, Kapa HM, Lange HLH, McRee A, Bonny AE. Healthcare barriers and utilization among adolescents and young adults accessing services for homeless and runaway youth. J Community Health 2017 Jun 5;42(3):437-443. [doi: 10.1007/s10900-016-0274-7] [Medline: 27817043]

27. Hudson A, Nyamathi A, Greengold B, Slagle A, Koniak-Griffin D, Khalilifard F, et al. Health-seeking challenges among homeless youth. Nurs Res 2010;59(3):212-218 [FREE Full text] [doi: 10.1097/NNR.0b013e3181d1a8a9] [Medline: 20404776]

28. Klein JD, Woods AH, Wilson KM, Prospero M, Greene J, Ringwalt C. Homeless and runaway youths' access to health care. J Adolesc Health 2000 Nov;27(5):331-339. [doi: 10.1016/s1054-139x(00)00146-4] [Medline: 11044705]

29. Slesnick N, Kang MJ. The impact of an integrated treatment on HIV risk behavior among homeless youth: a randomized controlled trial. J Behav Med 2008 Mar 17;31(1):45-59 [FREE Full text] [doi: 10.1007/s10865-007-9132-5] [Medline: 17940861]

30. Slesnick N, Kang MJ, Bonomi AE, Prestopnik JL. Six- and twelve-month outcomes among homeless youth accessing therapy and case management services through an urban drop-in center. Health Serv Res 2008 Mar;43(1 Pt 1):211-229 [FREE Full text] [doi: 10.1111/j.1475-6773.2007.00755.x] [Medline: 18211526]

31. Slesnick N, Feng X, Guo X, Brakenhoff B, Carmona J, Murnan A, et al. A test of outreach and drop-in linkage versus shelter linkage for connecting homeless youth to services. Prev Sci 2016 May 13;17(4):450-460. [doi:

10.1007/s11121-015-0630-3] [Medline: 26759145]

32. Naranbhai V, Abdool Karim Q, Meyer-Weitz A. Interventions to modify sexual risk behaviours for preventing HIV in homeless youth. Cochrane Database Syst Rev 2011 Jan 19(1):CD007501 [FREE Full text] [doi: 10.1002/14651858.CD007501.pub2] [Medline: 21249691]

33. Hosek S, Celum C, Wilson CM, Kapogiannis B, Delany-Moretlwe S, Bekker L. Preventing HIV among adolescents with oral PrEP: observations and challenges in the United States and South Africa. J Int AIDS Soc 2016;19(7(Suppl 6)):21107 [FREE Full text] [doi: 10.7448/IAS.19.7.21107] [Medline: 27760684] 
34. HIV PrEP framework. U.S. Department of Health \& Human Services. URL: $\underline{\text { https://www.aids.gov/federal-resources/policies/ }}$ prep-framework/ [accessed 2020-12-30]

35. Irvine MK, Chamberlin SA, Robbins RS, Kulkarni SG, Robertson MM, Nash D. Come as You Are: improving care engagement and viral load suppression among hiv care coordination clients with lower mental health functioning, unstable housing, and hard drug use. AIDS Behav 2017 Jun 24;21(6):1572-1579 [FREE Full text] [doi: 10.1007/s10461-016-1460-4] [Medline: 27342990]

36. Nyamathi A, Kennedy B, Branson C, Salem B, Khalilifard F, Marfisee M, et al. Impact of nursing intervention on improving HIV, hepatitis knowledge and mental health among homeless young adults. Community Ment Health J 2013 Apr 15;49(2):178-184 [FREE Full text] [doi: 10.1007/s10597-012-9524-z] [Medline: 22797748]

37. Nyamathi A, Liu Y, Marfisee M, Shoptaw S, Gregerson P, Saab S, et al. Effects of a nurse-managed program on hepatitis A and B vaccine completion among homeless adults. Nurs Res 2009;58(1):13-22 [FREE Full text] [doi:

10.1097/NNR.0b013e3181902b93] [Medline: 19092551]

38. Nyamathi A, Nahid P, Berg J, Burrage J, Christiani A, Aqtash S, et al. Efficacy of nurse case-managed intervention for latent tuberculosis among homeless subsamples. Nurs Res 2008;57(1):33-39 [FREE Full text] [doi: 10.1097/01.NNR.0000280660.26879.38] [Medline: 18091290$]$

39. Elliott K, W Klein J, Basu A, Sabbatini AK. Transitional care clinics for follow-up and primary care linkage for patients discharged from the ED. Am J Emerg Med 2016 Jul;34(7):1230-1235. [doi: 10.1016/j.ajem.2016.03.029] [Medline: 27066931]

40. Nyamathi AM, Nandy K, Greengold B, Marfisee M, Khalilifard F, Cohen A, et al. Effectiveness of intervention on improvement of drug use among methadone maintained adults. J Addict Dis 2011 Jan 30;30(1):6-16 [FREE Full text] [doi: 10.1080/10550887.2010.531669] [Medline: 21218306]

41. Nyamathi A, Branson C, Kennedy B, Salem B, Khalilifard F, Marfisee M, et al. Impact of nursing intervention on decreasing substances among homeless youth. Am J Addict 2012;21(6):558-565 [FREE Full text] [doi:

10.1111/j.1521-0391.2012.00288.x] [Medline: 23082836]

42. Nyamathi A, Marlow E, Branson C, Marfisee M, Nandy K. Hepatitis A/B vaccine completion among homeless adults with history of incarceration. J Forensic Nurs 2012 Mar;8(1):13-22 [FREE Full text] [doi: 10.1111/j.1939-3938.2011.01123.x] [Medline: 22372394]

43. Morgan BD, Rossi AP. Difficult-to-manage HIV/AIDS clients with psychiatric illness and substance abuse problems: a collaborative practice with psychiatric advanced practice nurses. J Assoc Nurses AIDS Care 2007 Nov; 18(6):77-84. [doi: 10.1016/j.jana.2007.06.001] [Medline: 17991601]

44. Ober AJ, Martino SC, Ewing B, Tucker JS. If you provide the test, they will take it: factors associated with HIV/STI Testing in a representative sample of homeless youth in Los Angeles. AIDS Educ Prev 2012 Aug;24(4):350-362 [FREE Full text] [doi: 10.1521/aeap.2012.24.4.350] [Medline: 22827904]

45. Rollnick S, Miller RW, Butler C. Motivational Interviewing in Health Care: Helping Patients Change Behavior. New York City: Guilford Press; Jul 01, 2008:45-6211-45-6211.

46. Kohler S, Hofmann A. Can motivational interviewing in emergency care reduce alcohol consumption in young people? a systematic review and meta-analysis. Alcohol Alcohol 2015 Mar;50(2):107-117. [doi: 10.1093/alcalc/agu098] [Medline: 25563299]

47. Cushing C, Jensen CD, Miller MB, Leffingwell TR. Meta-analysis of motivational interviewing for adolescent health behavior: efficacy beyond substance use. J Consult Clin Psychol 2014 Dec;82(6):1212-1218. [doi: 10.1037/a0036912] [Medline: 24841861]

48. Mbuagbaw L, Ye C, Thabane L. Motivational interviewing for improving outcomes in youth living with HIV. Cochrane Database Syst Rev 2012 Sep 12(9):CD009748. [doi: 10.1002/14651858.CD009748.pub2] [Medline: 22972147]

49. Wilson A, Nirantharakumar K, Truchanowicz E, Surenthirakumaran R, MacArthur C, Coomarasamy A. Motivational interviews to improve contraceptive use in populations at high risk of unintended pregnancy: a systematic review and meta-analysis. Eur J Obstet Gynecol Reprod Biol 2015 Aug;191:72-79. [doi: 10.1016/j.ejogrb.2015.05.010] [Medline: 26093351]

50. Santa Maria D, Narendorf C, Ha Y, Bezette - Flores N. Exploring contextual factors of youth homelessness and sexual risk behaviors: a qualitative study. Perspect Sex Reprod Health 2015;47(4):195-201 [FREE Full text]

51. Ha Y, Narendorf SC, Santa Maria D, Bezette-Flores N. Barriers and facilitators to shelter utilization among homeless young adults. Eval Program Plann 2015 Dec;53:25-33. [doi: 10.1016/j.evalprogplan.2015.07.001] [Medline: 26246453]

52. Ramsey M, Jolivette K, Patterson D, Kennedy C. Using choice to increase time on-task, task-completion, and accuracy for students with emotional/behavior disorders in a residential facility. Educ Treat Children 2010;33(1):1-21 [FREE Full text] [Medline: 20237209,20305798,20160979]

53. Schnell O, Hanefeld M, Monnier L. Self-monitoring of blood glucose: a prerequisite for diabetes management in outcome trials. J Diabetes Sci Technol 2014 May;8(3):609-614 [FREE Full text] [doi: 10.1177/1932296814528134] [Medline: 24876626] 
54. Scott-Sheldon LA, Carey MP, Vanable PA, Senn TE, Coury-Doniger P, Urban MA. Predicting condom use among STD clinic patients using the Information-Motivation-Behavioral Skills (IMB) model. J Health Psychol 2010 Oct;15(7):1093-1102 [FREE Full text] [doi: 10.1177/1359105310364174] [Medline: 20453055]

55. Comulada WS, Lightfoot M, Swendeman D, Grella C, Wu N. Compliance to cell phone-based ema among latino youth in outpatient treatment. J Ethn Subst Abuse 2015;14(3):232-250 [FREE Full text] [doi: 10.1080/15332640.2014.986354] [Medline: 26114764]

56. Cornelius JB, Cato M, Lawrence JS, Boyer CB, Lightfoot M. Development and pretesting multimedia HIV-prevention text messages for mobile cell phone delivery. J Assoc Nurses AIDS Care 2011;22(5):407-413 [FREE Full text] [doi: 10.1016/j.jana.2010.11.007] [Medline: 21256053]

57. Cornelius JB, Dmochowski J, Boyer C, St Lawrence J, Lightfoot M, Moore M. Text-messaging-enhanced HIV intervention for African American adolescents: a feasibility study. J Assoc Nurses AIDS Care 2013;24(3):256-267 [FREE Full text] [doi: 10.1016/j.jana.2012.06.005] [Medline: 23122907]

58. Sheoran B, Silva CL, Lykens JE, Gamedze L, Williams S, Ford JV, et al. YTH StreetConnect: development and usability of a mobile app for homeless and unstably housed youth. JMIR Mhealth Uhealth 2016 Jul 14;4(3):e82 [FREE Full text] [doi: 10.2196/mhealth.5168] [Medline: 27417882]

59. Wen CK, Schneider S, Stone AA, Spruijt-Metz D. Compliance with mobile ecological momentary assessment protocols in children and adolescents: a systematic review and meta-analysis. J Med Internet Res 2017 Apr 26;19(4):e132 [FREE Full text] [doi: 10.2196/jmir.6641] [Medline: 28446418]

60. Businelle M, Ma P, Kendzor DE, Reitzel LR, Chen M, Lam CY, et al. Predicting quit attempts among homeless smokers seeking cessation treatment: an ecological momentary assessment study. Nicotine Tob Res 2014 Oct;16(10):1371-1378 [FREE Full text] [doi: 10.1093/ntr/ntu088] [Medline: 24893602]

61. Narendorf SC, Santa Maria DM, Ha Y, Cooper J, Schieszler C. Counting and surveying homeless youth: recommendations from YouthCount 2.0!, a community-academic partnership. J Community Health 2016 Dec;41(6): 1234-1241. [doi: 10.1007/s10900-016-0210-x] [Medline: 27256409]

62. Preexposure prophylaxis for the prevention of HIV infection in the United States-2017 update: a clinical practice guideline. Centers for Disease Control and Prevention. URL: https://www.cdc.gov/hiv/pdf/risk/prep/cdc-hiv-prep-guidelines-2017. pdf [accessed 2021-04-22]

63. Dominguez KL, Smith DK, Thomas V, Crepaz N, Lang K, Heneine W, et al. Updated guidelines for antiretroviral postexposure prophylaxis after sexual, injection drug use, or other nonoccupational exposure to HIV—United States, 2016. Centers for Disease Control and Prevention. URL: https://www.cdc.gov/hiv/pdf/programresources/cdc-hiv-npep-guidelines. pdf [accessed 2021-04-22]

64. The McKinney-Vento definition of homeless. National Center for Homeless Education. URL: https://nche.ed.gov/ mckinney-vento-definition/ [accessed 2021-04-22]

65. Arozullah AM, Yarnold PR, Bennett CL, Soltysik RC, Wolf MS, Ferreira RM, et al. Development and validation of a short-form, rapid estimate of adult literacy in medicine. Med Care 2007 Nov;45(11):1026-1033. [doi: 10.1097/MLR.0b013e3180616c1b] [Medline: 18049342]

66. Tucker JS, D'Amico EJ, Ewing BA, Miles JNV, Pedersen ER. A group-based motivational interviewing brief intervention to reduce substance use and sexual risk behavior among homeless young adults. J Subst Abuse Treat 2017 May;76:20-27 [FREE Full text] [doi: 10.1016/j.jsat.2017.02.008] [Medline: 28340904]

67. Nyamathi A. Comprehensive health seeking and coping paradigm. J Adv Nurs 1989 Apr;14(4):281-290. [doi: 10.1111/j.1365-2648.1989.tb03415.x] [Medline: 2661620]

68. Kotchick BA, Shaffer A, Forehand R, Miller KS. Adolescent sexual risk behavior: a multi-system perspective. Clin Psychol Rev 2001 Jun;21(4):493-519. [doi: 10.1016/s0272-7358(99)00070-7] [Medline: 11413865]

69. Rotheram-Borus MJ, Song J, Gwadz M, Lee M, Van Rossem R, Koopman C. Reductions in HIV risk among runaway youth. Prev Sci 2003 Sep;4(3):173-187. [doi: 10.1023/a:1024697706033] [Medline: 12940468]

70. Arnold EM, Rotheram-Borus MJ. Comparisons of prevention programs for homeless youth. Prev Sci 2009 Mar;10(1):76-86 [FREE Full text] [doi: 10.1007/s11121-008-0119-4] [Medline: 19067164]

71. Kann L, Kinchen S, Shanklin SL, Flint KH, Kawkins J, Harris WA, Centers for Disease ControlPrevention (CDC). Youth risk behavior surveillance--United States, 2013. MMWR Suppl 2014 Jun 13;63(4):1-168. [Medline: 24918634]

72. Furukawa TA, Kessler RC, Slade T, Andrews G. The performance of the K6 and K10 screening scales for psychological distress in the Australian National Survey of Mental Health and Well-Being. Psychol Med 2003 Mar;33(2):357-362. [doi: 10.1017/s0033291702006700] [Medline: 12622315]

73. Kessler RC, Green JG, Gruber MJ, Sampson NA, Bromet E, Cuitan M, et al. Screening for serious mental illness in the general population with the K6 screening scale: results from the WHO World Mental Health (WMH) survey initiative. Int J Methods Psychiatr Res 2010 Jun;19 Suppl 1:4-22. [doi: 10.1002/mpr.310] [Medline: 20527002]

74. Nyamathi A, Hudson A, Greengold B, Leake B. Characteristics of homeless youth who use cocaine and methamphetamine. Am J Addict 2012;21(3):243-249 [FRE Full text] [doi: 10.1111/j.1521-0391.2012.00233.x] [Medline: 22494226]

75. Knight K, Simpson D, Morey JT. An evaluation of the TCU drug screen. National Institute of Justice, Office of Justice Programs, US Department of Justice. URL: https://www.ojp.gov/pdffiles1/nij/grants/196682.pdf [accessed 2021-04-30] 
76. LaVeist TA, Isaac LA, Williams KP. Mistrust of health care organizations is associated with underutilization of health services. Health Serv Res 2009 Dec;44(6):2093-2105 [FREE Full text] [doi: 10.1111/j.1475-6773.2009.01017.x] [Medline: $\underline{19732170}$ ]

77. Jemmott LS, Jemmott JB, Villarruel AM. Predicting intentions and condom use among Latino college students. J Assoc Nurses AIDS Care 2002;13(2):59-69. [doi: 10.1016/S1055-3290(06)60201-X] [Medline: 11936065]

78. Napper L, Fisher DG, Reynolds GL. Development of the perceived risk of HIV scale. AIDS Behav 2012 May;16(4):1075-1083 [FREE Full text] [doi: 10.1007/s10461-011-0003-2] [Medline: 21785873]

79. Golub SA, Gamarel KE, Rendina HJ, Surace A, Lelutiu-Weinberger CL. From efficacy to effectiveness: facilitators and barriers to PrEP acceptability and motivations for adherence among MSM and transgender women in New York City. AIDS Patient Care STDS 2013 Apr;27(4):248-254 [FREE Full text] [doi: 10.1089/apc.2012.0419] [Medline: 23565928]

80. Wilson CJ, Deane FP, Ciarrochi JV, Rickwood D. Measuring help-seeking intentions: properties of the general help-seeking questionnaire. Canadian J Counsel 2005;39(1):15 [FREE Full text]

81. Kidd SA, Carroll MR. Coping and suicidality among homeless youth. J Adolesc 2007 Apr;30(2):283-296. [doi: 10.1016/j.adolescence.2006.03.002] [Medline: 16631925$]$

82. INSTI HIV-1/HIV-2 rapid antibody test. U.S. Food and Drug Administration.: bioLytical Laboratories; 2014. URL: https:/ /www.fda.gov/media/79719/download [accessed 2020-07-29]

83. Pereira LE. Laboratory evaluation of a commercially available rapid syphilis test. Journal of clinical microbiology 2018;56(10):e00832-e00818. [doi: 10.1128/JCM.00832-18]

84. Reinhart R. Nurses continue to rate highest in honesty, ethics. Gallup. 2020 Apr 15. URL: https://news.gallup.com/poll/ 274673/nurses-continue-rate-highest-honesty-ethics.aspx [accessed 2021-04-30]

85. Bonin EB, Carlson C, Downing M, Hoeft J, Kalinowski A, Solomon-Bame J, et al. Adapting Your Practice: General Recommendations for the Care of Homeless Patients. Health Care for the Homeless Clinicians' Network and Council.: National Healthcare for the Homeless; 2010. URL: https://www.nhchc.org/resources/clinical/adapted-clinical-guidelines/ [accessed 2020-10-01]

86. Ending the HIV epidemic: overview. U.S. Department of Health \& Human Services. URL: https://www.hiv.gov/ federal-response/ending-the-hiv-epidemic/overview [accessed 2021-04-22]

87. Harpin S, Davis J, Low H, Gilroy C. Mobile phone and social media use of homeless youth in Denver, Colorado. J Community Health Nurs 2016;33(2):90-97. [doi: 10.1080/07370016.2016.1159440] [Medline: 27074405]

88. Jennings L, Lee N, Shore D, Strohminger N, Allison B, Conserve DF, et al. U.S. minority homeless youth's access to and use of mobile phones: implications for mhealth intervention design. J Health Commun 2016 Jul;21(7):725-733. [doi: 10.1080/10810730.2015.1103331] [Medline: 27232544]

\section{Abbreviations \\ CHSCF: Comprehensive Health Seeking and Coping Framework \\ COVID-19: coronavirus disease 2019 \\ HIV: human immunodeficiency virus \\ LGBTQ: lesbian, gay, bisexual, transgender, queer \\ STI: sexually transmitted infection}

Edited by G Eysenbach; submitted 22.12.20; peer-reviewed by T Lillie, T Phillips; comments to author 22.01.21; revised version
received 29.01.21; accepted 08.04.21; published 21.05.21
Please cite as:
Santa Maria D, Lightfoot M, Nyamathi A, Businelle M, Paul M, Quadri Y, Padhye N, Jones J, Calvo Armijo M
A Nurse Case Management HIV Prevention Intervention (Come As You Are) for Youth Experiencing Homelessness: Protocol for a
Randomized Wait-list Controlled Trial
JMIR Res Protoc 2021;10(5):e26716
URL: $\underline{\text { https://www.researchprotocols.org/2021/5/e26716 }}$
doi: $10.2196 / 26716$
PMID:

(CDiane Santa Maria, Marguerita Lightfoot, Adey Nyamathi, Michael Businelle, Mary Paul, Yasmeen Quadri, Nikhil Padhye, Jennifer Jones, Margarita Calvo Armijo. Originally published in JMIR Research Protocols (https://www.researchprotocols.org), 21.05.2021. This is an open-access article distributed under the terms of the Creative Commons Attribution License (https://creativecommons.org/licenses/by/4.0/), which permits unrestricted use, distribution, and reproduction in any medium, provided the original work, first published in JMIR Research Protocols, is properly cited. The complete bibliographic information, 
a link to the original publication on https://www.researchprotocols.org, as well as this copyright and license information must be included. 